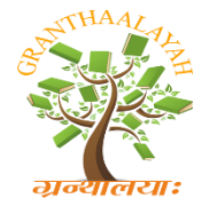

INTERNATIONAL JOURNAL OF RESEARCH GRANTHAALAYAH A knowledge Repository

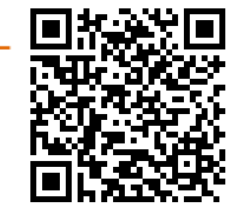

Social

\title{
A STUDY ON FAMILY ENVIRONMENT AND ITS EFFECT ON ACADEMIC ACHIEVEMENT IN SCIENCE AMONG SECONDARY SCHOOL STUDENTS
}

\author{
Jasar Pappattu*1, Mrs.J.Vanitha ${ }^{2}$ \\ ${ }^{* 1}$ MEd Scholar, RVS College of Education, India \\ ${ }^{2}$ Assistant Professor in Physics Education, RVS College of Education, India
}

DOI: https://doi.org/10.29121/granthaalayah.v5.i6.2017.2052

\begin{abstract}
Family environment seems to impact academic performance. Families in common and parents in specific, have often been considered to be the most significant support system obtainable to the child. The toughest factor in molding a child's character or behavior is the relationship with their parents. Students who have struggled educationally in most circumstances are at higher risk of school avoidance, and eventually dropping out, than those who are effective. For the struggling students, however, school is often a place that only helps to strengthen the low self-esteem. The student attempts to evade these state of mind of failure by staying home. The main motive is to study on family environment and its effect on academic achievement in science. This research is under taken with a view to examining the family environment and its effect on academic achievement in science among secondary school students with a sample size 300 from 8 schools of Palakkad district. Normative Survey method is used. The study concluded that there doesn't exist any relationship between family environment factors and achievement in science skills among secondary school students.
\end{abstract}

Keywords: Family Environment; Academic Achievement.

Cite This Article: Jasar Pappattu, and Mrs.J.Vanitha. (2017). "A STUDY ON FAMILY ENVIRONMENT AND ITS EFFECT ON ACADEMIC ACHIEVEMENT IN SCIENCE AMONG SECONDARY SCHOOL STUDENTS." International Journal of Research Granthaalayah, 5(6), 428-436. https://doi.org/10.29121/granthaalayah.v5.16.2017.2052.

\section{Introduction}

Good education does not come about by chance. It is a product of real teaching and learning together with the effort of the teacher, the school, the students, parents and their numerous home environments. Often at times the responsibilities on the poor performance of students in school are shifted to the teachers and the school authorities. Most people in our society seem not to give adequate consideration to the education of their children. It seems some of the parents have 
erroneous idea about the performance of their children, they do not know and seem to fulfill their role of guidance and encouragement in the child's performance in schools. Some people also have the notion that the mass failure or success in schools could be sketched back to the teachers and the school authorities. While other people see socio-economic status of the family as an effect to the child's academic performance. However, some research works have exposed that the performance of the students is a joint strength of both the school authorities and that of the parents in different home environment.

\subsection{Objectives of the Study}

There are two main types of objectives undertaken by the investigator in this study work.

\subsubsection{General Objectives}

- To find out the family environment among secondary school students.

- To find out the academic achievement among secondary school students.

- To adopt questionnaire on family environment among secondary school students.

\subsubsection{Specific Objectives}

- To find out the impact of personal variable like sex, locality, parent's educational qualification and parents occupation on family environment among secondary school students

- To study about the difference in the level of academic achievement in science among secondary school students.

- To find out the impact of personal variables like sex, locality, parent's educational qualification and parents occupation on academic achievement secondary school students

- To find out whether there exist significant mean score difference achievement in science between the groups based on family environment among secondary school students

- To find out whether there exist significant mean score difference academic achievement in science between boys and girls among secondary school students.

\section{Research Design}

The investigator adopted normative Survey method to study on family environment and academic achievement among secondary school students in Palakkad district. The study was conducted on representative sample of 300 secondary school students from 8 schools of Palakkad district. Stratified random sampling technique was used, giving due representation to variables like gender, locality and type of school.

\subsection{Variables of the Study}

This study tries to investigate the correlation of Family environment factors on achievement of science skills among secondary school students of Palakkad District. The select independent variable is family environment which include 
- Family environment of home.

- Family environment of school

- Family environment of society

The department variable is achievement of science skills.

Classificatory variables: Gender and locale are taken as classificatory variables.

Table 1: Component wise distribution of items in the family environment factor questionnaire

\begin{tabular}{|l|l|l|l|}
\hline No. & Components & Score & Percentage \\
\hline 1 & Family environment enrolment of home & 10 & $25 \%$ \\
\hline 2 & Family environment enrolment of school & 20 & $50 \%$ \\
\hline 3 & Family environment enrolment of society & 10 & $25 \%$ \\
\hline
\end{tabular}

Table 2: Details of schoolwise break-up of final sample

\begin{tabular}{|l|l|l|}
\hline SI.No. & Name of school & Locality \\
\hline 1 & MES HIGH SCHOOL, MANNARKKAD & URBAN \\
\hline 2 & HIGHER SECONDARY SCHOOL, SREEKRISHNAPURAM & RURAL \\
\hline 3 & GOVT. HIGHER SECONDARY SCHOOL, CHERPULASSERY & URBAN \\
\hline 4 & GOVT.HIGHER SECONDARY SCHOOL, ALANALLUR & RURAL \\
\hline 5 & B.E.M.HIGHER SECONDARY SCHOOL, PALAKKAD & URBAN \\
\hline 6 & HIGHER SECONDARY SCHOOL, MUNDUR & RURAL \\
\hline 7 & SABARI HIGHER SECONDARY SCHOOL, PALLIKURUP & URBAN \\
\hline 8 & GOVT. HIGHER SECONDARY SCHOOL, PULAPATTA & RURAL \\
\hline
\end{tabular}

\section{Testing the Hypotheses}

\section{HYPOTHESIS 1:}

There will be significant difference in the mean scores of family environment factors of secondary school students for the sub sample based on gender and locale.

\section{Locale}

For comparing the family environment factors of high school students among urban and rural independent $\mathrm{t}$-test was carried out. Results of the test of significance along with mean and standard deviation of the scores of the two groups are given in the table.

Table 3: Results of the test of significant difference in the mean scores of family environment factors of high school students for the sub sample based on locale

\begin{tabular}{|l|l|l|l|l|l|}
\hline Variable & Locale & $\mathbf{N}$ & Mean & Standard deviation & Critical ratio \\
\hline Family environment factors & Urban & 150 & 33.3625 & 5.07992 & $0.285 \#$ \\
\cline { 2 - 7 } & Rural & 150 & 33.4575 & 4.33071 & \\
\hline
\end{tabular}

\#Not significant at both levels. 


\section{Discussion of Results}

For comparing the family environment factors of urban and rural data from 150 students in the table 3, both urban and rural were utilized. Critical value computed for comparing the score of the family environment factors of urban and rural $(-0.285)$ is found to be less than the table values (1.96 and 2.58) at 0.05 and 0.01 levels of significance. Hence it can be concluded that there exist no significant difference in the mean scores of family environment factors of high school students for the sub sample based on locale.

\section{Gender}

For comparing the family environment factors of secondary school students among boys and girls, independent t-test was carried out. Results, of the test of significance along with mean and standard deviation of the scores of the two groups are as follows:

Table 4: Results of the test of significant difference in the mean scores of family environment factors of high school students for the sub sample based on gender.

\begin{tabular}{|l|l|l|l|l|l|}
\hline Variable & Gender & $\mathbf{N}$ & Mean & Standard deviation & Critical ratio \\
\hline Family environment factors & Boys & 150 & 33.20 & 4.99674 & $1.260 \#$ \\
\cline { 2 - 7 } & Girls & 150 & 33.62 & 4.41694 & \\
\hline
\end{tabular}

\#Not significant at both levels.

\section{Discussion of Results}

For comparing the family environment factors of boys and girls from the table 4, data from 150 students, both boys and girls were utilized. Critical value (-1.26) is found to be less than the tabled value (1.96 and 2.58) at 0.05 and 0.01 levels of significance. Hence it can be concluded that there exist no significant difference in the mean scores of family environment factors of high school students for the sub sample based on gender.

\section{HYPOLTHESIS 2:}

There will be significant difference in the mean scores of achievement in science skills of high school students for the sub sample based on gender and locale.

\section{Gender}

For comparing the achievement of science skills of high school students among boys and girls, independent t-test was carried out. Results of the test of significance along with mean and standard deviation of the scores of the two groups are given in the table.

Table 5 : Results of significant difference in the mean scores of achievement in science skills of high school students based on gender.

\begin{tabular}{|c|c|c|c|c|c|}
\hline Variable & Gender & $\mathbf{N}$ & Mean & $\begin{array}{l}\text { Standard } \\
\text { deviation }\end{array}$ & Critical ratio \\
\hline \multirow{2}{*}{$\begin{array}{l}\text { Achievement in science } \\
\text { skills }\end{array}$} & Boys & 150 & 16.395 & 6.37853 & $1.438 \#$ \\
\hline & Girls & 150 & 17.0325 & 6.1572 & \\
\hline
\end{tabular}

\#Not significant at both levels. 


\section{Discussion of Results}

For comparing the achievement in science skills of boys and girls in Table 5, data from 150 students, both boys and girls were utilized. Critical value (-1.438) is found to be less than the tabled value (1.96 and 2.58) at 0.05 and 0.01 levels of significance. Hence there exists no significant difference in the mean scores of achievement in science skills based on gender.

\section{Locale}

To compare the achievement in science skills of high school students among urban and rural independent t-test was carried out. Results of the test of significance along with mean and standard deviation of the scores of the two groups are given below:

Table 6: Results of significant difference in the mean scores of achievement in science skills of high school students for the sub sample locale

\begin{tabular}{|c|c|c|c|c|c|}
\hline Variable & Gender & $\mathbf{N}$ & Mean & Standard deviation & Critical ratio \\
\hline \multirow{2}{*}{$\begin{array}{l}\text { Achievement in science } \\
\text { skills }\end{array}$} & Urban & 150 & 16.8125 & 6.55475 & $0.445 \#$ \\
\hline & Rural & 150 & 16.615 & 5.98467 & \\
\hline
\end{tabular}

\#Not significant at both levels.

\section{Discussion of Results}

Comparison of achievement in science skills of urban and rural students in the Table 6, data from 150 students, were utilized. Critical ratio (0.4450) is less than the tabled value (1.96 and 2.58) at 0.05 and 0.01 levels of significance. Hence it can be concluded that there exists no significance difference in the mean scores of achievement in science skills based on locale.

\section{HYPOTHESIS 3:}

Test of significance of the correlation coefficients, between family environment factors and achievement in science skills of high school students for total sample and sub sample based on gender and locale.

The relationship between family environment factors and achievement in science skills of high school students was calculated by using Karl Pearson's product moment coefficient of correlation. The details of analysis are presented below:

Table 7: Results of significant relationship between the variables among secondary school students for total sample.

\begin{tabular}{|l|l|l|l|}
\hline Sample & Size & Coefficient of correlation & Critical ratio \\
\hline Total & 300 & 0.048 & $1.3575 \#$ \\
\hline
\end{tabular}

\#Not significant at both levels.

\section{Discussion of Results}

The Table 7 reveals that for total sample the correlation between the variables family environment factors and achievement in science skills were found to be 0.048 . This shows that there exist a negligible positive correlation the variables. The calculated t-value (1.3575) is less than the tabled value (1.96 and 2.58) required for significant at 0.05 and 0.01 levels of significance. Therefore ' $r$ ' is found to be not significant. 


\section{Gender}

Table 8: Results of significant relationship between family environment factors and achievement in science skills among high school students based on gender.

\begin{tabular}{|l|l|l|l|l|}
\hline Nature of the sample & Sub sample & Size & Coefficient of correlation & Critical ratio \\
\hline \multirow{2}{*}{ Gender } & Boys & 150 & 0.02637 & $0.5248 \#$ \\
\cline { 2 - 5 } & Girls & 150 & 0.069203 & $1.3835 \#$ \\
\hline
\end{tabular}

\#Not significant at both levels.

\section{Discussion of Results}

The Table 8 reveals that the value of the coefficient of correlation between the variables for boys and girls were found to be $0.02637,0.0692$ respectively.

This value shows that there exists a negligible positive correlation between the two variables. The calculated t-value for boys(0.5248) is less than that of the tabled value 1.96 and 2.58 . this shows that the hypothesis, there exists no significant relation between the variables family environment factors and achievement in science skills among boys. Similarly the calculated $t$ value for girls(1.3835) is less than that of the tabled value 1.96 and 2.58 . This shows that there exist no significant relation between family environment factors and achievement in science skills among girls.

\section{Locale}

Table 9: Results of significant relationship between family environment factors and achievement in science skills among high school students based on locale.

\begin{tabular}{|l|l|l|l|l|}
\hline Nature of the sample & Sub sample & Size & Coefficient of correlation & Critical ratio \\
\hline \multirow{2}{*}{ Locale } & Rural & 150 & 0.0685 & $1.3699 \#$ \\
\cline { 2 - 5 } & Urban & 150 & 0.03276 & $0.6537 \#$ \\
\hline
\end{tabular}

\#Not significant at both levels.

\section{Discussion of Results}

The Table 9 reveals that the value of the coefficient of correlation between the variables family environment factors and achievement in science skills for rural and urban were found to be 0.0685 and 0.032756 respectively. This shows that there exist a negligible positive correlation between the two variables. The calculated t-value for rural $(0.0685)$ is less than that of the tabled value 196 and 2.58. This shows that there exist no significant relation between variables among rural students.

The calculated t-value for urban (0.032756) is less than that of the tabled value 1.96 and 2.58 . This shows that there exist no significant relation between the variables among urban students.

\section{HYPOTHESIS 4:}

There will be significant difference in relationship between family environment factors and achievement in science skills among high school students for the sub-sample based on gender and locale. 


\section{Gender}

Test significance of difference ' $r$ ' is used to compare the differences in ' $r$ ' between the variables family environment factors and achievement in science skills among high school students classified on the basis of gender and locale.

Table 10: Results of significant difference in relationship between family environment factors and achievement in science skills among high school students based on gender.

\begin{tabular}{|l|l|l|l|l|l|l|l|l|}
\hline $\begin{array}{l}\text { Nature of sub } \\
\text { samples }\end{array}$ & \multicolumn{2}{|l|}{$\begin{array}{l}\text { Size of the } \\
\text { sample }\end{array}$} & \multicolumn{2}{l|}{$\begin{array}{l}\text { Coefficient } \\
\text { correlation }\end{array}$} & \multicolumn{2}{|c|}{ z-values } & \multicolumn{2}{|c|}{ t-value } \\
\hline Gender & Boys & N1 & 150 & r1 & 0.0263 & z1 & 0.0263 & $0.708 \#$ \\
\cline { 2 - 10 } & Girls & N2 & 150 & r2 & 0.0692 & z2 & 0.0692 & \\
\hline
\end{tabular}

\#Not significant at both levels.

\section{Discussion of Results}

The Table 10 reveals that the coefficient of correlation between the variables for boys and girls are 0.0263 and 0.0692 and the z-values are 0.0263 and 0.0692 respectively. The calculated tvalue (0.708) is less than the tabled value 1.96 and 2.58. so it can be concluded, that there exists no significant difference between the variables family environment factors and achievement in science skills among girls and boys.

\section{Locale}

Table 11: Results of significant difference in relationship between family environment factors and achievement in science skills among high school students based on locale.

\begin{tabular}{|l|l|l|l|l|l|l|l|l|}
\hline $\begin{array}{l}\text { Nature of sub } \\
\text { samples }\end{array}$ & & \multicolumn{2}{|l|}{$\begin{array}{l}\text { Size of the } \\
\text { sample }\end{array}$} & $\begin{array}{l}\text { Coefficient } \\
\text { correlation }\end{array}$ & of & \multicolumn{2}{|l|}{ z-values } & t-value \\
\hline \multirow{2}{*}{ Locale } & Rural & N1 & 150 & r1 & 0.0685 & z1 & 0.0685 & $0.715 \#$ \\
\cline { 2 - 10 } & Urban & N2 & 150 & r2 & 0.0327 & z2 & 0.0327 & \\
\hline
\end{tabular}

\#Not significant at both levels.

\section{Discussion of Results}

The Table 11 reveals that the coefficient of correlation between the variables for rural and urban are 0.0685 and 0.0327 and the $\mathrm{z}$-values are 0.0685 and 0.0327 respectively. The calculated $\mathrm{t}$ value (0.715) is less than the tabled value 1.96 and 2.58. so it can be concluded that there exists no significant difference between the variables family environment factors and achievement in science skills among rural and urban students.

\section{Conclusion}

Based on the results obtained from the present study, "A Study of Family environment factors, as a correlate on achievement of science skills among high school students', revealed that there doesn't exist any relationship between family environment factors and achievement in science skills among high school students. 


\subsection{Tenability of the Hypotheses}

Based on the findings, the tenability of the hypotheses set for the study was examined and the following conclusions are made.

\subsubsection{Hypothesis 1}

First hypothesis states that there will be significant difference in the mean scores of family environment factors of high school students for the sub sample based on gender and locale.

Results of the analysis shows that there does not exist a significant difference in the mean scores of family environment factors of high school students for the sub sample based on gender and locale. For both the sub sample the t-value is rejected at both level of significance.

This suggests that first hypothesis cannot be substantiated.

\subsubsection{Hypothesis 2}

Second hypothesis states that there will be significant in science skills of high school students for the sub sample based on gender and locale.

Results of the analysis shows that there is no significant difference in the means scores of achievement in science skills is noticed in the two cases-locale and gender. The t-value is rejected at both levels of significance.

This suggests that second hypothesis cannot be substantiated.

\subsubsection{Hypothesis 3}

Third hypothesis states that there will be significant relationship between family environment factors and achievement in science skills among high school students for total sample and sub sample based on gender and locale.

The calculated value of $r$ and $t$ shows that there is no significant, negligible relationship between family environment factors and achievement in science skills among high school students for total sample and sub sample based on gender and locale.

This suggests that third hypothesis cannot be substantiated.

\subsubsection{Hypothesis 4}

Fourth hypothesis states that there will be significant difference in relationship, between family environment factors and achievement in science skills among high school students for the sub sample based on gender and locale.

The calculated value of ' $r$ ' and ' $t$ ' shows that there is no significant difference negligible correlation between family environment factors and achievement in science skills among high 
school students for the sub sample based on gender and locale. The t-value is rejected at both level of significance.

This suggests that Fourth hypothesis cannot be substantiated.

\section{References}

[1] Sadanandam \& M.V.Lourdusamy, (2011). Parental Influence on Academic Achievement of Higher Secondary Students. Edutracks 11(1), 33-39.

[2] Anandan, K. and Kumar, K.P. (2011). Influence of parent's education and occupation on the achievement in physics among matriculation students of Krishnagiri, District Tamilnadu. Journal of Education Research and Extension,48(2).

[3] Babu, R and Mummoorthy, R. (2011), "A study on the family environment of higher secondary students", Journal of Educational Research and Extension, 41, 1, Pp. 50-55.

[4] Vasanthi, A. \& Sutherman, S. (2011). Study habits and academic achievement of XI standard students in Palani Educational District. Edutracks, 10(11), 39 - 42.

[5] Radhakanta Gartia (2010), Correlates of Academic achievement and family environment of graduates students. Journal of Educational Research \& Extension, Vol.47 (3) p.69.

[6] Amutha Sree, N. \& Krishnamurthy, S. (2010). Academic Achievement of Commerce students in relation to their Study habits. Research Reflections on Education, 8(2). 14-17. 